\title{
Urszula Panicz
}

Uniwersytet im. Adama Mickiewicza w Poznaniu

Kreowanie dyskursu publicznego w Polsce rola mediów krytycznych wobec Prawa i Sprawiedliwości

\section{WPROWADZENIE}

$\mathrm{P}$ o KATASTROFIE SMOLEŃSKIEJ w licznych przekazach medialnych chętnie podkreślano symptomy, które miały świadczyć o poprawie jakości polskiej debaty politycznej. Dyskurs ten rzeczywiście uległ przekształceniu, w szczególności niemal wszystkie media zaczęły prezentować pozytywny wizerunek Lecha Kaczyńskiego ${ }^{1}$. Ponadto, o rugowanie agresji językowej z przestrzeni publicznej apelowali wiodący politycy. Pełniący obowiązki Prezydenta RP Marszałek Sejmu, Bronisław Komorowski twierdził, że „ofiara tragicznie zmarłych w katastrofie pod Smoleńskiem nie może być daremna i powinna wzywać do pojednania polsko-polskiego i polsko-rosyjskiego"2.

Złagodzenie języka polskiej polityki okazało się chwilowe. Niebawem politycy ponownie zaczęli prowadzić dyskurs, w którym przeciwnika ideowego prezentowano jako wroga. Warto podkreślić, że emocjonalna dyskusja obfitowała w absurdy oraz pomówienia ${ }^{3}$. Coraz częściej polityzowano zagadnienia religijne, a zwłaszcza działalność Kościoła katolickiego. Sytuacji w najmniejszym stopniu nie zmieniło utworzenie Stowarzyszenie Polska Jest Najważniejsza, które deklarowało, że będzie dążyć do tego, by poprawić jakość publicznej

${ }^{1}$ Gubisz ostrość, Katastrofa smoleńska - konsekwencje i czego nie przyniosła, „Lubczasopismo” http://gubiszostrosc.salon24.pl/220631, katastrofa-smolenskakonsekwencje-i-czego-nie-przyniosla, 10.01.2011 r.

${ }^{2} \mathrm{PAP}$, Komorowski: ofiara ze Smoleńska powinna wzywać do pojednania, „Polska Times. Warszawa”, http://www.polskatimes.pl/warszawa/aktualnosci/24566o,komo rowski-ofiara-ze-smolenska-powinna-wzywac-do-pojednania,id,t.html, o8.01.2011 r.

${ }^{3}$ Przejawem pogorszenia debaty publicznej był powstały po katastrofie smoleńskiej film „Mgła”. Zgodnie z deklaracjami jego twórców, miał on wyjaśnić i wskazać winnych tragedii smoleńskiej. Bardzo dyskusyjne okazały się sposób i dobór argumentów oraz to, kto wypowiadał się w dokumencie. M. Dłużewska, J. Lichocka, Mgła, http://www. youtube.com/watch?v=rKNCKq3Tfl8, 10.01.2011 r. 
debaty ${ }^{4}$. Tomasz Lis, obserwując rozwój wypadków, sugerował wręcz, że „wojna toczy się o polityczną przyszłość, ale wstępem do niej jest ba-

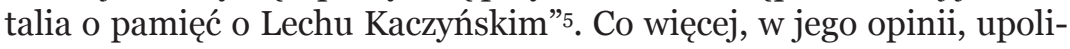
tycznienie katastrofy smoleńskiej było „skrajnie cyniczne, ale i na swój sposób logiczne"'.

Ponowne zaostrzenie dyskursu politycznego świadczyć może, iż polska kultura polityczna opiera się na dychotomicznym widzeniu świata. Taką perspektywę przyjęli nie tylko politycy, lecz w dużej mierze, także dziennikarze.

Nie ulega wątpliwości, że przejawia się ona w dywagacjach mediów na tematy polityczne, w medialnych ocenach poczynań władzy, a także w stronniczych komentarzach. Analizując działalność polskich dziennikarzy z lat 2005-2011, trudno nie zgodzić się z Jeanem Baudrillardem, który twierdził, że „media nie pełnią w ogóle funkcji komunikacyjnej, nie komunikują, nie łączą, ale raczej dzielą i izolują7”.

\section{Rola MEdiów w DEbacie PUbliczNeJ w Polsce}

NALEŻY PRZYPUSZCZAĆ, że zaangażowanie mediów w konflikty polityczne wynika ze swoistej logiki, według której działają współczesne środki przekazu. Trzeba zwrócić uwagę na fakt, że media przestały pełnić

${ }^{4}$ A. Kublik, Klub Polska Jest Najważniejsza, „Gazeta Wyborcza” 2010, nr 274, s. 7, http://szukaj.wybor cza.pl/Archiwum/1,0,7319608,20101124RP-DGW,Klub_Polska_Jest_Najwazniejsza,zwykly.html, 10.01.2011 r.

${ }^{5}$ T. Lis, Wojna smoleńska, „Wprost”, http://www.wprost.pl/ar/202435/Wojna-smolenska/, o8.01.2011 r.

${ }^{6}$ Rozwijając ten komentarz, dziennikarz twierdził, że zwłaszcza w opinii polityków PiS: „oto mamy już układ ponadnarodowy, mamy spisek Tuska i Putina”. Według T. Lisa, z perspektywy Prawa i Sprawiedliwości, Tusk, to wróg wewnętrzny, zaś Putin, to wróg zewnętrzny. Pierwszy to ten, który prowadził zbrodniczą politykę i ma krew na rękach. Ten drugi natomiast ,jak zawsze jest zły, bo jest Ruskiem”. Użycie słowa „Rusek” wpisuje się w dawny schemat myślowy, a tym samym retorykę, związaną z Radiem Maryja. Radio to poparło Jarosława i Lecha Kaczyńskich oraz Prawo i Sprawiedliwość. Należy zwrócić uwagę, że zdaniem I. Kamińskiego, rozgłośnia ta jest ksenofobiczna, zaś L. Kaczyński niejako propagował jego wartości. Zob. I. Krzemiński, Czego nas uczy Radio Maryja? Socjologia treści i recepcji rozgłośni, Warszawa 2009, s. 20, 126-129. T. Lis twierdził również, że teza o zamachu na Prezydenta RP była politycznie użyteczna. Podkreślał, że odwołując się do niej, PiS wróciło do dawnej retoryki, w której dominowało dychotomiczne widzenie świata, poszukiwanie spisku oraz wroga. Mówił także o sporze wokół krzyża przed Pałacem Prezydenckim. Jego zdaniem, krzyż ten „nazywany symbolem żałoby Polaków, służy jako kij do okładania wroga. Mamy tu do czynienia z totalną instrumentalizacją symboli religijnych. Kto chce krzyża przed pałacem - jest patriotą, kto nie chce, patriotą nie jest. Jeśli więc Komorowski go tam nie chce, to w Pałacu Prezydenckim jest co najwyżej intruzem i uzurpatorem".

${ }^{7}$ M. Drożdż, Media. Teorie i fikcje, Kielce 2005, s. 76. 
funkcję informacyjną na rzecz funkcji zabawowej oraz zarobkowej. Wiąże się to ze zmianą programową, po części też estetyczną, których przejawem jest rosnąca popularność sensacji, spektaklu, plotki, czy tzw. reality show ${ }^{8}$. Obserwuje się spadek popytu na rzetelną informację, a przyczyny takiego stanu rzeczy wydają się być złożone 9 . W pogoni za uwagą odbiorców media kreują rzeczywistość, która nie zawsze jest prawdziwa i coraz częściej współtworzona przez audytoria. J. Baudrillard nazywa ją „,hiperrzeczywistością”, wskazując, że aktualnie nasila się tendencja, by czynić widza aktorem medialnego spekta$\mathrm{klu}^{10}$. Kluczowe i chyba najważniejsze jest jednak zaangażowanie ludzi pracujących w mediach, którzy jako ostatni decydują o formie i treści przekazywanych informacji.

Nieustanne odpowiadanie mediów na potrzeby odbiorcy objawia się $\mathrm{w}$ nieświadomym zaangażowaniu w powstające konflikty. Czasem jest to zabieg celowy, zwłaszcza gdy uzna się, że opowiadanie się po jednej ze stron przynosi wymierne korzyści finansowe. Wymowne jest również nieustanne zajmowanie się przez media napiętymi relacjami między Platformą Obywatelską i Prawem i Sprawiedliwością. Środki przekazu usiłują zdobyć jak najszerszą widownię, co powoduje, że w trakcie selekcji wybiera się temat najatrakcyjniejszy, który pozwala utrzymać wiernych widzów lub pozyskać nowych odbiorców. Co więcej, czasem, zwłaszcza w artykułach publicystycznych, ingeruje się w temat, opatrując tekst niejednozacznym tytułem, prowokująco, oburzająco $^{11}$. Wypada też podkreślić, że ludzie tworzący media, politycy oraz odbiorcy wzajemnie na siebie oddziałują: audytorium otrzymuje pożądaną formę, media uzyskują korzyści ekonomiczne, zaś niektórzy politycy są promowani przez wybranych graczy medialnych.

Ulegając wszystkim opisanym wyżej tendencjom, polskie media pozostają spolityzowane. Polityzacja przejawia się nie tylko w re-

\footnotetext{
${ }^{8}$ Jean Baudrillard zdefiniował reality show jako coś, co wyrywa z życia i zmusza do odegrania w telewizji psychodramy walki z AIDS, czy rozpadu małżeństwa. Zwrócił tym samym uwagę na negatywną moc tego gatunku, która przejawia się w tym, że ludzie nie tyle gromadzą się przed telewizorami, ale są przeciągani na drugą stronę ekranu. Problem polega na niemożliwości rozróżnienia sztuki od rzeczywistości. Zob. J. Baudrillard, Zbrodnia doskonała, Warszawa 2008, s. 35-48.

${ }^{9}$ Można przypuszczać, że telewizja wpływa na gusta (także polityczne) widzów poprzez sposób przedstawiania informacji. Z drugiej strony należy rozważyć problem, czy to nie widzowie kreują ramówki telewizyjne, a media nie starają się sprostać wymaganiom swych widzów. Na pewno koło pozostaje zamknięte: między widzami a mediami istnieje sprzężenie zwrotne. Kwestia zysków i strat jest kontrowersyjna.

${ }^{10}$ Zob. J. Baudrillard, Zbrodnia..., op. cit.

${ }^{11}$ Jest to jeden ze sposobów manipulacji, o czym w dalszej części tekstu.
} 
akcjach na bieżące wydarzenia polityczne, lecz również w opiniach dziennikarzy odnośnie tego, kto ponosi winę zarówno za tragedię smoleńską, jak i za pogorszenie stanu dyskursu politycznego w Polsce. Równocześnie, media spekulowały i spekulują na temat możliwości poprawy jakości debaty publicznej, podkreślając negatywne skutki zaostrzających się konfliktów ${ }^{12}$.

W rezultacie w polskim dyskursie medialnym, podobnie jak w dyskursach zagranicznych, tradycyjne funkcje mediów ustępują nowym ${ }^{13}$. Zgodnie z ujęciem J. Baudrillarda, „właściwa funkcja mediów polega na tworzeniu fikcji, iluzji i symulacji"14. Jego zdaniem, cała społeczność ma charakter medialny, zaś pozamedialny świat nie istnieje. Oznacza to, że media nie informują o rzeczywistości, ale ją tworzą. Skoro tak, to zasadną wydaje się również teza, zgodnie z którą środki przekazu odpowiadają za stan debaty publicznej. Twierdzenie to można wesprzeć jeszcze dwiema innymi przesłankami. Po pierwsze, współczesne media stają się wiodącym źródłem informacji o świecie. Po drugie, silnie oddziałując na opinię publiczną, kreują wizerunki polityków poprzez ukazywanie ich w różnych okolicznościach. Znaczenie może mieć tu wszystko: od czasu i miejsca, gdzie polityk zostanie zaprezentowany, do sposobu ukazania oraz komentarza, jakim zostanie opatrzona informacja. Ponadto, jak zauważył J. Baudrillard, dziennikarze pozostają silnie powiązani ze strukturami władzy ${ }^{15}$.

${ }^{12}$ Wielu dziennikarzy twierdziło i twierdzi, że ostry spór pomiędzy PO i PiS znacząco wpłynął na pogorszenie wizerunku Polski za granicą. Początkowo twierdzono, że głównymi odpowiedzialnymi za taki stan rzeczy są bracia Kaczyńscy. Wally Olin, brytyjski specjalista od marek i stylu, zatrudniony ponad trzy lata temu przez Krajową Izbę Gospodarczą, by zmienić wizerunek Polski jako zaściankowego kraju na bardziej nowoczesny, uważał wręcz, że bracia Kaczyńscy „to z punktu widzenia public relations katastrofa, szargająca imię kraju”. Zob. mar, PAP, „Daily Telegraph”: Polscy przywódcy psują wizerunek kraju, w: „Gazeta Wyborcza”, http://wiadomosci.gazeta.pl/wiadomosci/1,74655,4542746.html, 05.01.2011 r. Natomiast w opinii L. Wałesy wizerunek Polski „To wizerunek ośmieszony, który powoli przekształca się w farsę i tragikomedię”, PAP, Watęsa $w$ „La Repubblica”: „Wizerunek Polski staje się farsa i tragikomedia”, w: „Gazeta Wyborcza”, http://wiadomosci.gazeta.pl/Wiadomosci/1,80708,4460977. html, 05.01.2011 r.

${ }^{13}$ Według Harolda Lasswella funkcjami mediów są: nadzorowanie otoczenia, korelowanie reakcji grup w ramach społeczeństwa na jego otocznie oraz transmisja kulturowego. Charles R. Wright dodaje też rozrywkę jako czwarty element, pozostający obok wyżej wymienionych składników komunikacji masowej. Zob. D. McQuail, Teoria komunikowania masowego, Warszawa 2007, s. 111-113.

${ }^{14}$ Zob. M. Drożdż, Media..., op. cit., s. 74 .

${ }^{15}$ Ibidem, s. 75 . 


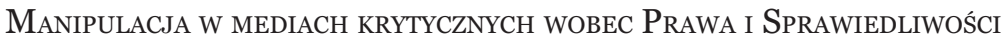

MoŻNA WSKAZAĆ KILKA CZYNNIKów, które po roku 2005 silnie warunkowały zaostrzanie polskiej debaty politycznej. Po pierwsze, charakteryzując spory między Platformą Obywatelską a Prawem i Sprawiedliwością, media określały je jako „wojnę” ${ }^{16}$. Po drugie, środki przekazu były stronnicze - w wielu relacjach dotyczących stosunków politycznych w Polsce dziennikarze prezentowali własne preferencje, często a priori opowiadając się za PO i przeciw PiS ${ }^{17}$. Maciej Iłowiecki wyliczył „12 grzechów głównych mediów”18, które wpływają na przekaz, czyniąc go manipulatywnym. Wszystkie można odnaleźć w materiałach tworzonych przez dziennikarzy w Polsce w latach 2005-2011. Wszystkie służyły także kreowaniu „medialnej wojny” pomiędzy dwiema najsilniejszymi polskimi partiami ${ }^{19}$.

Po pierwsze, media niechętne PiS, polityzując się, często manipulowały tytułami i lead'ami, opierając się na zasadzie, wedle której treść artykułu wypada szybciej z pamięci albo też tytuł potrafi ją skutecznie przesłoniće ${ }^{20}$. Również w przekazach telewizyjnych, czy radio-

${ }^{16}$ Gazety pisały o „wojnie politycznej”, „wojnie PO-PiS”, „wojnie POPiSowej”, „billboardowej wojnie” - niemal we wszystkich periodykach padało słowo „wojna”. Rzeczywiście stosunki obu tych partii były napięte, niemniej wydaje się, że publikacje wyostrzające konflikt jednocześnie sprzyjały jego zaostrzaniu.. Spór jawił się jako permanentny i fundamentalny. Niektórzy badacze uważają, że mediom zależało na podtrzymywaniu takiej wizji z racji tego, że jej upowszechnienie oznaczało dla nich korzyści zarówno finansowe, jak i polityczne. Zob. Media Watch, Już wiemy, dlaczego władzy tak zależało na „Wiadomościach”. Teraz Stońce Peru świeci jak trzeba, http://www. wpolityce.pl/view/3819/Juz_wiemy_dlaczego_wladzy_tak_zalezalo_na_Wiadomosciach_Teraz_Slonce_Peru_swieci_jak_trzeba.html, 05.01.2011 r..; Por. też wypowiedź Ireneusza Krzemińskiego: „(...) Media żyją tą wojną, karmią się nią, a nawet mają swój interes, żeby ją podsycać”; F. Tyszka, Media $w$ Polsce nie spetniają swojej misji, „Super Express”, http://www.se.pl/wydarzenia/kraj/media-w-polsce-nie-speniaja-swojej-misji_107270.html, 05.01.2011 r.

${ }^{17}$ Por. Już wiemy..., op. cit.

${ }^{18}$ M. Iłowiecki, Krzywe..., op. cit.

${ }^{19}$ Należy zauważyć, że zdaniem M. Iłowieckiego, nie wszyscy dziennikarze ulegają naciskom i stosują manipulację. Częstokroć walczą z nimi, demaskując ich próby. Co więcej, nierzadko manipulacja jest wynikiem niedouczenia i niekompetencji. Zob. M. Iłowiecki, Krzywe zwierciadło. O manipulacji w mediach, Lublin 2003, s. 113.

${ }^{20}$ Ibidem. Co więcej, współczesne tempo obiegu informacji sprawia, że nie zawsze jest czas, aby przeczytać cały artykuł. Pułapką jest też to, że w trakcie przekazu ustnego na żywo nie można powrócić do momentu, w którym nastąpiło niezrozumienie. Często nie ma czasu na refleksję. J. Baudirllard pisał: „W społeczeństwach nazbyt szybkich, na podobieństwo naszych, efekt realności natomiast zanika, nazbyt wielkie przyspieszenie prowadzi bowiem do zderzenia przyczyn ze skutkami, w wyniku powstałych zaburzeń zatraca się liniowość, rzeczywistości zaś w jej względnej ciągłości brakuje już czasu, 
wych, z których zapamiętuje się pierwsze informacje lub obrazy, zauważalna była taka tendencja. W rezultacie mylące tytuły oraz leady mogły utrwalać w świadomości odbiorców treść odbiegającą od prawdy. Tytul, który pojawił się 1 lipca 2008 r. na platformie internetowej TVN24, tj. „Rząd PiS chciał zapłacić za budowę tarczy”, wpisywał się w schemat manipulacji. Sugerowano w nim, że chęć zapłaty była faktem, tymczasem z treści tekstu wynikało, że jedynie mówił o niej Sławomir Nowak z PO, któremu przeczyli posłowie PiS ${ }^{21}$. Innym przykładem był tytuł, który pojawił się na portalu internetowym interia.pl: „Spór o samolot: Jednak to premier był pierwszy”. Tytuł sugerował, że to Prezes Rady Ministrów zaczął konflikt, natomiast w rzeczywistości chodziło o wysłanie notatki o potrzebie wylotu przez niego tuż przed Prezydentem RP22.

Kolejną techniką stosowaną przez medialnych przeciwników PiS było operowanie lękiem, agresją i seksem ${ }^{23}$. Na początku sporu PO-PiS media nieprzychylne partii J. Kaczyńskiego używały tej metody bardzo często. M. Iłowiecki nadmienił, że celem omawianej techniki jest „wyeksponowanie informacji o zagrożeniach, powstałych w wyniku działań innych podmiotów, przeciwników politycznych lub instytucji, które chce się wyeliminować” ${ }^{24}$ po to, by lęk został „przerzucony” na politycznego przeciwnika i był z nim utożsamiany. Zabieg ten stosowano m.in. w prezentacjach sylwetki J. Kaczyńskiego. Media charakteryzowały tego polityka poprzez używanie sformułowań zaczerpniętych z wojskowości, znanych z reportaży i wspomnień wojennych ${ }^{25}$. Tytuły wielu artykułów w polskich czasopismach podtrzymywały atmosferę zagrożenia $^{26}$. To sprawiło, że J. Kaczyński był kojarzony z układem,

by zaistnieć”. Por. J. Baudrillard, Zbrodnia..., op. cit., s. 60.

${ }^{21}$ Zob. bgr, jk/pra, „Rząd PiS chciat zaplacić za budowe tarczy”, „TVN24”, http://www.tvn24.pl/12690,1555767,0,22,rzad-pis-chcial-zaplacic-za-budowetarczy, wiadomosc.html, 05.01.2011 r.

${ }_{22}$ Por. Spór o samolot: jednak to premier byt pierwszy, „interia.pl/dziennik.pl”, http://fakty.interia.pl/polska/news/spor-o-samolot-jednak-to-premier-byl-pierwszy,1197596, 05.01.2011 r.

${ }^{23}$ Wojciech Muszyński tę technikę nazywa „tworzeniem wizji zagrożenia”. Zob. W. Muszyński, Wizerunek Lecha i Jarosława Kaczyńskich w mediach $w 2005$ roku, [w:] Media a polityka, red. A. M. Zarychta, Ł. Donaj, Łódź 2007, s. 181-182.

${ }^{24}$ M. Iłowiecki, Krzywe..., op. cit., s. 138.

${ }^{25}$ W. Muszyński, Wizerunek..., op. cit., s. 181-182.

${ }^{26}$ Tytuły pojawiające się w „Newsweek Polska”, dotyczące Kaczyńskich: Jak zatrzymał ofensywę Kaczyńskich?; Czy mamy się już bać? Tytuł z „Wprost”: Bliźniacza siła. Tytuły generowały nastrój, jaki był kreowany przez media za czasów rządów Kaczyńskich. Co więcej, zdaniem W. Muszyńskiego, medialny wizerunek „nie odpowiada w peł- 
IV RP, „kaczyzmem”27 i autorytaryzmem²8.

Warte zauważenia jest to, że niektórzy autorzy wyrażali wręcz opinię, że D. Tusk „ustawił” ${ }^{29}$ sobie dziennikarzy, ponieważ „bez względu na to, co robi, nie robi, spapra ma bardzo wysokie notowania [zaufania] i żadnych dociekliwych pytań" 30 . Jednocześnie część mediów „w bardzo negatywnym świetle” przedstawiała „wszelkie działania Kaczyńskiego i PiS" ${ }^{11}$. Zadaniem tej partii, jako głównego ugrupowania opozycyjnego, jest krytyka rządu. Niemniej wielu dziennikarzy niechętnie odnosiło się i nadal odnosi do takich działań ${ }^{32}$.

$\mathrm{Z}$ badań CBOS wynika ponadto, że w Polsce niejednokrotnie większym zaufaniem elektoratu cieszą się politycy, którzy prezentują swoje racje wyraziściej ${ }^{33}$. Taki wynik może wiązać się z manipulowaniem emocjami, tzn. sytuacją, w której nie ma znaczenia to, czy polityk mówił mądrze, czy nie, czy kłamał, czy mówił prawdę, gdyż odbiorcy zapamiętują go przez pryzmat emocji. Wiąże się to z wcześniej omówioną techniką manipulacji strachem. Część mediów zatem przedstawiała J. Kaczyńskiego negatywnie, a D. Tuska odwrotnie. Odbiorcy nie zawsze interpretowali słowa polityków, a wizerunek polityka, niekorzystnie przedstawianego przez media, zdawał się być decydujący dla poziomu zaufania. Jarosław Macała wskazał, że PiS nie potrafiło się porozumieć ani z mediami publicznymi, ani z komercyjnymi ${ }^{34}$. Wśród powodów tego stanu rzeczy, odwołując się do opinii Pawła Lisickiego,

ni rzeczywistości”. Zob. W. Muszyński, Wizerunek..., op. cit., s. 173.

${ }^{27}$ Termin po raz pierwszy użyty w lutym 2005 roku przez Roberta Mazurka i Igora Majewskiego z tygodnika „Wprost”. Dla samego Kaczyńskiego nie określenie nie było negatywne, gdyż interpretował kaczyzm jako „silne państwo z uporządkowanym systemem prawnym, który chroni obywateli i przed samowolą urzędników i przed przestępcami, dba też o interesy wszystkich grup społecznych. Zob. W. Muszyński, Wizerunek..., op. cit., s. 176-177.

${ }^{28}$ „Wygrała wizja państwa zagrożonego przez kaczyzm, czyli autorytarne rządy PiS, wykorzystujące jakoby służby specjalne do walki z politycznymi przeciwnikami. U podstaw owej redefinicji konfliktu leżał skuteczny bunt establishmentu (nie elit!) III RP”. Tak o wygranych przez PO wyborach w 2007 roku wypowiadała się socjolog Barbara Fedyszak-Radziejowska. Zob. k.b., Skuteczna obrona establishmentu, „Rzeczpospolita”, http://www.rp.pl/artykul/65594.html, 05.01.2011 r.

29 PCM, Paradoks zaufania do polityków, „Lubczasopismo”, http://lubczasopismo.salon24.pl/dialogspoleczny/post/243646,paradoks-zaufania-do-politykow, 05.01.2011 r.

${ }^{30}$ Ibidem.

${ }^{31}$ Ibidem.

${ }^{32}$ Ibidem.

${ }^{33}$ Ibidem. W artykule wskazano na badania CBOS.

${ }^{34} \mathrm{~J}$. Macała, TVP w „IV RP” - ciągłość czy zmiana? [w:] Media..., op. cit., s. 256-257. 
wymienił wcześniejsze „nieprzyjacielskie działania prezesa PiS w stosunku do mediów publicznych"35. Stosunek do mediów komercyjnych mógł również zaważyć na negatywnym przedstawianiu J. Kaczyńskiego. W 2006 r. zasiadająca w KRRiT z ramienia PiS, Elżbieta Kruk dwukrotnie ukarała TV Polsat karą w wysokości 500 tys. zł oraz upomniała Radio TOK FM ${ }^{36}$.

$\mathrm{Z}$ wyżej omówionymi metodami wiąże się również medialne nagłaśnianie inwektyw i „określeń - utrwalaczy”37, które mogą „narzucać osądy z góry i utrwalać pewne opinie" ${ }^{38}$. Tak stało się z inwektywą użytą przez Stefana Niesiołowskiego w stosunku do PiS: „rząd J. Kaczyńskiego to rząd trzech «k»: kłamstwo, kołtuństwo i kolesiostwo" 39 . Jeszcze silniej media nagłośniły fakt, iż Janusz Palikot określił braci Kaczyńskich jako „kurdupli”40. W 2007 r. urzędnicy Centrum Informacyjnego Rządu stworzyli kilkusetstronicowy raport zawierający obraźliwe wypowiedzi PO wobec Kaczyńskich oraz $\mathrm{PiS}^{41}$.

Media krytyczne wobec PiS stosowały również technikę insynuacji. Użyto jej m.in. w wyemitowanym w TVP filmie dokumentalnym „Dramat w trzech aktach”. Nadano go w czasie, gdy Lech Kaczyński zaczął gromadzić spore poparcie elektoratu ${ }^{42}$. W dokumencie bracia Kaczyńscy byli oskarżani o poważne przestępstwa dotyczące FOZZ ${ }^{43}$.

${ }^{35}$ „Lider PiS atakowany jest mocniej niż pozostali politycy tej partii. Oliwy do ognia dolał także sam niezręczną wypowiedzią o tym, że w Polsce nie ma wolnych mediów”, J. Macała, TVP..., op. cit., s. 257-258.

${ }^{36}$ TV Polsat została ukarana za emisję rozmowy Kuby Wojewódzkiego z Kazimierą Szczuką, podczas której K. Szczuka przedrzeźniała głos niepełnosprawnej Magdaleny Buczek, założycielki podwórkowych kółek różańcowych. Przyczyną drugiej kary była emisja w TV Polsat reality show „Nieustraszeni”, podczas której uczestnicy zjadali dżdżownice. Radio TOK FM upomniano m.in. za naruszenie etyki dziennikarskiej spowodowane rozmową na temat seksu przed ślubem i lekceważeniem nauki Kościoła oraz osób, które stawały w jej obronie. Zob. K. Kowalczyk, Prawo i Sprawiedliwość a mass media, [w:] Media a demokracja, red. L. Pokrzycka, W. Mich, Lublin 2007, s. 94-95.

${ }^{37}$ M. Iłowiecki, Krzywe..., op. cit., s. 127.

${ }^{38}$ Ibidem.

${ }^{39} \mathrm{ak}$, „PiS to kłamstwo, koltuństwo i kolesiostwo”, „Wirtualna Polska”, http://wiadomosci.wp.pl/kat, 1342,title,PiS-to-klamstwo-koltunstwo-i-kolesiostwo,wid,9058118, wiadomosc.html, 05.01.2011 r.

$4^{\circ 0}$ Qba, Lech Kaczyński skarży się na „kurdupla”, „Super Express”, http://www. se.pl/wydarzenia/kraj/ prezydent-skarzy-sie-na-kurdupla_127822.html, 05.01.2011 r.

${ }^{41}$ Por. mawro, Spis obraźliwych wypowiedzi polityków PO wobec braci Kaczyńskich i rządu PiS, „Gazeta Wyborcza”, http://wyborcza.pl/8,75402,4648561.html, 05.01.2011 r.

${ }^{42}$ M. Iłowiecki, Krzywe..., op. cit., s. 123.

${ }^{43}$ Fundusz Obsługi Zadłużenia Zagranicznego. Zob. http://www.abcnet.com.pl/ node/3211, 06.01.2011 r. 
Po katastrofie smoleńskiej Witold Gadomski wykazywał, że J. Kaczyński często operuje zarzutami, które nie znajdują poparcia w dowodach ${ }^{44}$. Przykładem była katastrofa smoleńska. Mówiąc o katastrofie TU-154 jako nieprzypadkowej, J. Kaczyński sugerował, że była ona wynikiem spisku. Media skwapliwie nagłaśniały podejrzliwe wypowiedzi lidera PiS, m.in. tę, w której twierdził: „Zła polityka, polityka napastowania politycznych konkurentów, odmawiania im godności i ich poniżania kończy się źle, kończy się tragicznie"45.

Środki przekazu krytyczne wobec wiodącej partii opozycyjnej chętnie wykorzystywały i wykorzystują „metodę autorytetów pozornych”, czyli cytują wypowiedzi „przywódców opinii”, np. aktorów czy reżyserów ${ }^{4}$. Przykładem była chociażby wypowiedź Marka Kondrata ${ }^{47}$, w której mówił on o swoich politycznych preferencjach ${ }^{48}$.

Poza przytoczonymi wyżej „manipulacjami medialnymi”49, można wymienić również inne techniki, jak na przykład stronnicze przedstawianie, czy tworzenie atmosfery nieufności.

Stronnicze przedstawianie wpływało na zaostrzanie stosunków między partiami. Było to szczególnie widoczne w 2005 r., w czasie i tuż po kampanii prezydenckiej. Jak podkreślał Wojciech Muszyński: „autorzy tekstów próbowali przekonać, że osoby wybierające L. Kaczyńskiego nie podjęły dojrzałej decyzji, a jedynie bały się zaryzykować i zaufać D. Tuskowi (lub w pierwszej turze innemu z kandydatów)"50. Wizerunek nowo wybranego Prezydenta RP przedstawiano bardzo krytycznie: skupiano się przede wszystkim na słabościach, wadach aniżeli zaletach ${ }^{51}$. We „Wprost” pisano o L. Kaczyńskim jako mistrzu

${ }^{44}$ W. Gadomski, Język insynuacji. Kaczyński zdejmuje maskę, „Gazeta Wyborcza”, http://wyborcza.pl/1,76842,8034134,Jezyk_insynuacji_Kaczynski_zdejmuje_maske.html, 06.01.2011 r.

${ }^{45}$ Ibidem.

${ }^{46}$ M. Iłowiecki, Krzywe..., op. cit., s.131.

${ }^{47}$ Marek Kondrat podkreślał: „i ta radość we mnie wzbierała. Głównie wynikająca z tego, że PiS odchodzi! Tamta ulga trwa do dzisiaj razem z - już umiarkowanym - lękiem, że mogą wrócić”. Zob. D. Nogal, Stawny aktor boi się powrotu PiS. Ty tė̇?, „Pardon”, http://www.pardon.pl/artykul/10148/slawny_aktor_boi_sie_powrotu_pis_ty_ tez_glosuj, 01.04.2011 r.

${ }^{48}$ Jak pisał M. Iłowiecki: „Ekspert może nam jasno wyjaśnić, o co chodzi w danej informacji, jakie są możliwości i rozwiązania danego problemu i jakie będą ewentualne skutki danego rozwiązania. Ale ekspert nie powinien określać, co jest normą moralną i pełnić właśnie roli autorytetu społecznego. Chyba, że z innych względów zasłużył na to miano". Zob. M. Iłowiecki, Krzywe..., op. cit., s. 132.

${ }^{49}$ Ibidem.

${ }^{50}$ W. Muszyński, Wizerunek..., op. cit., s. 174 .

${ }^{51}$ Ibidem. 
wkręcania, człowieku roztargnionym i bałaganiarskim ${ }^{52}$. Dla porównania D. Tusk był przedstawiany pozytywnie i naturalnie, choć nieco ironicznie: „Ma $178 \mathrm{~cm}$ wzrostu, waży ok. $75 \mathrm{~kg}$, lubi herbatę i kartoflankę gotowaną przez mamę, pasjonuje się historią, zwłaszcza Gdańska, i piłką nożną"53.

Atmosfera nieufności wiązała się z operowaniem lękiem i agresją. Społeczeństwo otrzymywało od mediów informacje, które podważały lub umniejszały rolę Kaczyńskich jako opozycjonistów w PRL. Dziennikarze często zarzucali im również autorytaryzm i niezdolność do kompromisów.

Medialne manipulacje wizerunkami polityków PiS wynikały z motywów głównie ekonomicznych, lecz również politycznych. Dla niektórych dziennikarzy, czy stacji najważniejsze było i nadal jest nagłośnienie sprawy, która mogłaby wzbudzić sensację, zwiększyć zainteresowanie stacją lub gazetą, a tym samym przynieść wymierne korzyści finansowe. Często dochodziło do upubliczniania wiadomości niesprawdzonych, które były pożądane z punktu widzenia odbiorców ${ }^{54}$.

W rezultacie wypada skonstatować, że brak prawdomówności w mediach pozostaje ważnym problemem. J. Baudrillard mówił o hiperrzeczywistości jako konsekwencji „wciągnięcia” widza do telewizora i stania się przez niego jednym z uczestników spektaklu. Jest to tylko przenośnia, a jednak ma odniesienie do komunikacji politycznej w Polsce. Obecnie trudno jest odróżnić prawdę od kłamstwa, a media, które winny stać na straży prawdy, obiektywizmu, rzetelności, przestały wypełniać tę funkcję.

\section{PRZEMOC KOMUNIKACYJNA W POLITYCE JAKO DETERMINANTA}

\section{KULTURY POLITYCZNEJ}

NALEŻY PODKREŚLIĆ, że manipulatywna postawa mediów krytycznych wobec PiS skutkuje przekazami, które nie pozwalają właściwie ukazać dyskursu politycznego w Polsce. Wprawdzie na podstawie wizerunków medialnych wiadomo, że komunikacja między partiami ulega zaostrzeniu. Niemniej nie sposób w oparciu o nie trafnie i szczegółowo scharakteryzować powody tego stanu rzeczy.

${ }^{52}$ A. Blinkiewicz, R. Mazurek, Lech, brat Jarosława, „Wprost”, http://www.wprost. $\mathrm{pl} / \mathrm{ar} / 82345 /$ Lech-brat-Jaroslawa/?O=82345\&pg=3, 06.01.2011 r.

${ }_{53}$ „Jestem gwarancją spokoju”, „Interia.pl”, http://wybory2005.interia.pl/aktualnosci/news?inf $=674147,06.01 .2011 \mathrm{r}$.

${ }^{54}$ Zob. L. Szot, „News” a odpowiedzialność dziennikarza za stowo, [w:] Wojna $w$ mediach, red. B. Nierenberg, W. Piątkowska-Stepaniak, Opole 2007, s. 56-57. 
Chcąc zrealizować to zadanie, można natomiast odwołać się do koncepcji gruntowniej przemyślanych, np. autorstwa Marcina Króla.Należy jednak zaznaczyć, że w historii Polski nieraz zdarzały się momenty, gdy komunikacja polityczna gwałtownie się zaostrzała, ulegając silnemu nasyceniu mową nienawiści ${ }^{55}$. Jednak zaostrzenie debaty politycznej w latach 2005-2011 ma oczywiście swoje osobliwości. Jak zauważył Mariusz Staniszewski, nie służy Polakom, ponieważ znacząco kompromituje ich kraj za granicą ${ }^{56}$. Nadto, politycy przerzucając całą swą energię na walkę z przeciwnikiem, są bierni w obszarze reform: „Konkurencja ośrodków władzy powoduje chaos w kraju. Prezydent zawetował już 14 ustaw (...). Z kolei rząd, przygotowując kolejne ustawy, konsekwentnie ignoruje prezydenta jako pełnoprawny podmiot polityczny. Znając stanowisko L. Kaczyńskiego w sprawie prywatyzacji szpitali, koalicja forsowała ustawę, która zakładała przekształcenie wszystkich palcówek służby zdrowia w spółki. Nie próbowała nawet uzgodnić z prezydentem kompromisu, który otwierałby drogę do reformy" 57 .

Taki stan jest konsekwencją stosowania przemocy komunikacyjnej w polityce, co skutkuje brakiem dialogu ${ }^{58}$. M. Król tłumaczył niepodejmowanie przez polityków rzeczywistej dyskusji kilkoma powodami. Po pierwsze, możliwość rozmowy na argumenty jest wykluczona

55 Tzw. „wojna na górze”, czyli konflikt między Lechem Wałęsą, przewodniczącym Niezależnego Związku Zawodowego „Solidarność”, a rządem Tadeusza Mazowieckiego w 1990 r. Skutkiem jest podział sceny politycznej. Zob. B. Kozłowski, Przemówienie Watęsy w Pucku - początek „wojny na górze”, "Polska.pl”, http://kalendarium.polska.pl/wydarzenia/article.htm?id=224855, 07.01.2011 r.; A. Chwalba, Wojna na górze, wojna na zawsze, „Polityka.pl”, http://www.polityka.pl/historia/204526,1,wojna-na-gorze-wojna-na-zawsze.read, 07.01.2011 r.

${ }^{56}$ Wiodącym powodem kompromitacji Polski na szczycie Unii Europejskiej w 2009 r. była ostra rywalizacja na arenie krajowej. Wzajemna niechęć L. Kaczyńskiego i D. Tuska sprawiła, że Polska przestała się liczyć w walce o najważniejsze stanowiska w UE. Znamienne było zachowanie Prezydenta RP, który wbrew woli premiera RP udzielił poparcia premierowi duńskiemu. Grzegorz Kostrzewa-Zorbas komentował to w ten sposób: „Udzielając za darmo poparcia premierowi Danii, prezydent osłabił pozycję negocjacyjną Polski w staraniach o inne ważne funkcje w Unii”. Zob. M. Staniszewski, Wojna na górze niszczy i kompromituje państwo, „Polska Times”, http:// www.polskatimes.pl/stronaglowna/102099,wojna-na-gorze-niszczy-i-kompro mituje-panstwo,id,t.html, 07.01.2011 r.

${ }^{57}$ Ibidem.

${ }^{58} \mathrm{~W}$ niektórych filozofiach politycznych przyjmuje się, że siła jest efektywną metodą osiągania celów politycznych. Zwolennicy tej tezy twierdzą, że posługiwanie się siłą w polityce jest nieuchronne, a jej stosowanie wyklucza rozmowę (pomijając przypadki wyjątkowe). Zob. M. Król, Siła i przemoc $w$ polityce,[w:]: Filozofia polityczna, Kraków 2008, s. 271. 
ze względu na przekonanie o wszechobejmującej irracjonalności natury ludzkiej. Ludzie przyjmujący takie założenie, w opinii M. Króla, niezdolni są do zachowań racjonalnych, nie potrafią rozsądnie rozmawiać, a tym samym podejmować decyzji politycznych. W rezultacie stosują przemoc komunikacyjną, gdyż muszą ją stosować - ich irracjonalna natura nie pozwala na korzystanie $\mathrm{z}$ racjonalnych metod ${ }^{59}$. Rozmowa między skłóconymi ugrupowaniami: PiS oraz PO nie dochodzi zatem do skutku ze względu na ułomności, lecz również wadliwe wyobrażenia obu stron. Znamienną sytuacją była próba stworzenia koalicji PO-PiS, która okazała się bezskuteczna. Partie nie potrafiły się porozumieć, nie były zdolne zawrzeć kompromisów. Do tego wszystkiego dochodziła jeszcze odmienność interesów.

Diametralna różnica światów wartości, przekonanie o niepodważalności własnych racji, a nawet przeświadczenie o tym, że powinno się innych nauczyć, jak należy osiągać szczęście ${ }^{60}$ - wszystkie te cechy występują w myśleniu polityków obu ugrupowań i zadecydowały definitywnie o fiasku koalicji. Każda ze stron może się nadto obawiać, że „dając choć trochę” przekroczy granicę „dawania w ogóle”, a przez to okaże się słaba, co może wykorzystać przeciwnik. Obie grupy boją się utraty pozycji i obie chcą dominować, zyskiwać przewagę, a nie ją wyrównywać, czy tracić. M. Król twierdzil, że w Polsce brakowało i brakuje kompromisu o charakterze ideowym, czy filozoficznym, który był i jest potrzebny młodej demokracji. Według niego, kompromis w Polsce oznacza zabieg czysto taktyczny, tj. „wymianę przysług mającą na uwadze wyłącznie interes prywatny”. W rezultacie „zwykle zmienia się w polityczny szantaż, który ze zgodą, a tym bardziej wspólnym dobrem, nie ma już nic wspólnego"61. Takie rozumienie kompromisu, zdaniem M. Króla, doprowadziło m.in. do szantażu, który stanowił główną przyczynę ratyfikacji traktatu lizbońskiego. W jego opinii, w trakcie głosowania nad układem doszło do poparcia partii rządzącej przez opozycję (w tym SLD), jak również do wykluczenia PiS. M. Król stwierdzil, że „SLD wyciąga tylko takie sprawy, których poruszanie jest wprawdzie charakterystyczne dla lewicy i dla liberałów, ale stawia rząd PO w niezręcznej sytuacji (in vitro, religia w szkole itd.). W nagrodę za zaniechanie tych drugorzędnych z lewicowego, ale pierwszorzędnych z kościelnego punktu widzenia kwestii SLD oczekuje życzliwości partii

${ }^{59}$ Ibidem, s. 271-272.

${ }^{60}$ Ibidem, s. 272.

${ }^{61}$ M. Król, Spór i kompromis, „Dziennik.pl”, http://wiadomosci.dziennik.pl/wydarzenia/artykuly/74218, spor-i-kompromis.html, 07.01.2011 r. 
rządzących. (...) Zarówno ze strony PiS, jak i SLD nie mamy do czynienia nawet $\mathrm{z}$ kompromisem techniczno-taktycznym, ale ze zwyczajnym szantażem" ${ }^{62}$. Zgodnie z ujęciem M. Króla, można więc wnioskować, że w polskiej polityce partie wolą nieformalnie szantażować, niż formalnie ustępować. Tym samym nie może być tak, że wygrywają najlepsze merytorycznie projekty, czy ci, którzy mają najwięcej do powiedzenia. Zwyciężają ci, którzy wystosowali najefektywniejszy szantaż, czyli taki, który pozwala przeforsować ustawę za cenę późniejszego współmiernego odwdzięczenia się za to.

$\mathrm{Z}$ racji pluralizmu wartości $\mathrm{w}$ polskiej polityce $\mathrm{w}$ XXI w. istnieją płaszczyzny, w których ugrupowania w całości się zgadzają, jednak są też kwestie, w których strony odrzucają jakiekolwiek negocjacje. W efekcie, zdaniem M. Króla, często dochodzi do rezygnacji z uczestnictwa w milczeniu, czyli tolerancji ${ }^{63}$. Spór wówczas eskaluje, gdyż nikt nie potrafi zaakceptować inności przeciwnika. Typowym przykładem takiego stanu rzeczy była wspomniana już niezdolność koalicyjna PO i PiS: „Obie strony pozostały przy swoich zdaniach - spór dotyczył tego, czy program rządzenia ma przedstawić PiS, a PO się do niego ustosunkować - co proponowała Platforma, czy też - jak chciało PiS obie partie mają go wypracować wspólnie" ${ }^{64}$.

Kolejnym powodem, dla którego w polskiej polityce brakuje uczciwej rozmowy, to sprzeczność interesów ${ }^{65}$. W opinii M. Króla, bywa ona często urojona, ponieważ gracze polityczni nie są skorzy do poszukiwania rozwiązań korzystnych dla wszystkich. Każde ugrupowanie natomiast uznaje swe racje za ważniejsze, co skutkuje tym, że brakuje punktu wspólnego (zaczepnego) rozmowy. Co więcej, sprzeczność interesów - prawdziwa lub wyimaginowana - może ujawniać się i niekiedy ujawnia w toku uzgadniania stanowisk, jak np. w wypadku PO i PiS. Partie toczyły rozmowy na temat koalicji kilkukrotnie, aby w końcu stwierdzić, że się nie porozumieją, bo mają odmienne postulaty: PO chciało m.in., by Bronisław Komorowski został Marszałkiem Sejmu, na co PiS się nie zgadzało ${ }^{66}$. W 2009 r., gdy prezydentem był Lech Kaczyński, a premierem Donald Tusk, dochodziło również do konflik-

${ }^{62}$ Ibidem.

${ }^{63}$ M. Król, Siła..., op. cit., s. 272.

${ }^{64}$ Biuro Prasowe Prawa i Sprawiedliwości, Pierwsze rozmowy koalicyjne PiS - PO, „pis.org.pl” http://www.wybory2005.pis.org.pl/article.php?id=103, 07.01.2011 r.

${ }^{65}$ M. Król, Siła..., op. cit., s. 272.

${ }^{66}$ P. Wroński, Koniec koalicji?, „Gazeta Wyborcza”, http://wiadomosci.gazeta.pl/ Wiadomosci/1,80273, 2988330.html, 07.01.2011 r. 
tów, spowodowanych sprzecznością interesów. Najbardziej rażący był „spór obu ośrodków władzy w sprawie wprowadzenia w Polsce euro". Zdaniem M. Króla, „uzgodnienie jednolitego stanowiska podniosłoby wartość złotego i zwiększyło wiarygodność Polski w oczach inwestorów. Żadna ze stron nie próbuje jednak nawet słuchać argumentów konkurentów. Dlatego wartość naszej waluty spadła, a Polacy płacą wyższe raty kredytowe"67.

Podsumowując, wypada stwierdzić, że w świetle koncepcji M. Króla, a wbrew stanowisku mediów krytycznych wobec PiS, właściwie wszystkie ugrupowania w Polsce kierują się swoistą, niewysublimowaną filozofią polityczną. Prowadzi ona do braku rozmowy oraz przemocy komunikacyjnej, gdyż politycy „uważają, że świat jest już tak urządzony, iż w polityce decyduje siła" ${ }^{68}$. Polscy gracze polityczni z różnych opcji stosują szantaż, gdyż są przekonani, iż stanowi on środek uniwersalny, skuteczny w każdych okolicznościach. W szczególności dwie najsilniejsze partie wpisują się wyraźnie w schemat działania polegający na utrzymywaniu wrogich stosunków. W rezultacie zarówno PO, jak PiS wykluczają rozmowę, jednocześnie demonstrując oczekiwanie, że to ta druga strona pierwsza się odezwie.

\section{DELIBERATYWNA DEMOKRACJA: SPOSÓB NA ZŁAGODZENIE KONFLIKTÓW} W POLSKIEJ DEBACIE?

JAKOŚĆ POLSKIEJ DEBATY PUBLICZNEJ, jak wyżej wskazano, zależy od wielu czynników, pośród których dominują jednak niechęć do dyskusji oraz skłonność polityków do nadużywania przemocy komunikacyjnej. Powstaje zatem pytanie, czy mankamenty te można wyeliminować poprzez nasycenie polskiego systemu politycznego instytucjami o charakterze deliberatywnym.

Należy podkreślić, że zdaniem M. Króla, jeżeli przyjmie się, że ludzie są nieskończenie irracjonalni, polityka nie jest i nigdy nie będzie sferą konwersacji. Niemniej takie założenie nie jest stwierdzeniem faktu, lecz raczej deklaracją opcji światopoglądowej. Jej akceptacja prowadziłaby do stwierdzenia, że jakiekolwiek działania zmierzające do eliminacji przemocy komunikacyjnej skazane są na fiasko. Tymczasem liczne doświadczenia państw demokratycznych, w tym Polski, dowodzą, że stosowanie właściwych w danym miejscu i czasie mechanizmów konwersacyjnych prowadzi do złagodzenia rywalizacji

\footnotetext{
${ }^{67}$ M. Staniszewski, Wojna..., op. cit.

${ }^{68}$ M. Król, Siła..., op. cit., s. 272.
} 
politycznej. Często w warunkach zaostrzonego konfliktu jego rozwiązanie rozpoczyna się od wytyczenia przez strony procedur namysłu nad zastaną sytuacją, gdyż ten sposób rozpoczyna się długi ciąg deliberacyjny, polegający na wymianie i konfrontacji argumentów. W jego ramach „znaczenia nabierają argumenty mocniejsze, które jednak same podlegają udoskonalaniu”. W ten sposób formuje się „demokracja deliberatywna” lub inaczej „demokracja ucząca się”, czyli „proces dyskusji pozwala na poszukiwanie nowych rozwiązań, które wcześniej przez uczestników wspólnoty politycznej nie były dostrzegane" ${ }^{69}$. Wydaje się, że najważniejszym elementem takiej demokracji jest dyskusja, prowadząca do wspólnego wypracowywania rozwiązań. Co więcej, w takiej dyskusji pojawiać mogą się racje, które prezentują obywatele i przedstawiciele władz ${ }^{70}$.

Mocną stroną deliberowania jest tzw. zasada ostrożności oraz ograniczony spór, które mają hamować ewentualne rozszerzenie polemiki poprzez poszukiwanie sposobów na zmniejszenie różnic oraz kierowanie się wzajemnym szacunkiem. Ważne jest też, aby spór nie przenosił się na inne konkretne sprawy ${ }^{71}$.

Zaletą demokracji deliberatywnej jest również dążenie stron do ustalenia co najmniej minimalistycznej koncepcji dobra wspólnego. Nie ma tu miejsca na zabawę, czy ćwiczenie swoich talentów retorycznych. Dochodzi do wypracowania uczciwych zarówno dla jednostek, jak i społeczeństwa, zasad współpracy, rozumianych jako dobro wspólne ${ }^{72}$.

Upowszechnienie schematów deliberacyjnych w polskiej przestrzeni politycznej mogłoby prowadzić do sytuacji, w której liczne spory światopoglądowe przeniesiono by w sferę prywatną. Takie rozwiązanie godziłoby się z koncepcjami konwersacji Richarda Rorty'ego oraz Johna Rawlsa. Byli oni zwolennikami światopoglądowych sporów prywatnych, ponieważ twierdzili, że „demokracja służy pokojowemu rozwiązywaniu potencjalnych i aktualnych konfliktów oraz doprowadzeniu do kompromisu, natomiast nie wszystkie konflikty mogą zostać zażegnane przez zawarcie kompromisu, gdyż w bardzo wielu funda-

${ }^{69}$ A. Peisert, Demokracja deliberatywna: utopia czy ratunek dla demokratycznych wartości?, „kulturaliberalna.pl”, http://kulturaliberalna.pl/2010/o1/12/peisert-demokracja-deliberatywna-utopia-czy-ratunek-dla-demokratycznych-wartosci/, 10.01.2011 r.

${ }^{70}$ Zob. M. Król, Rozmowa, [w:] Filozofia..., op. cit., s. 172.

${ }^{71}$ Ibidem, S. 172-173.

${ }^{72}$ Ibidem, s. 174-175. 
mentalnych sprawach moralnych, religijnych, filozoficznych czy nawet estetycznych kompromis jest nie do wyobrażenia"73. W ich opinii, rozmowa publiczna na takie niedopuszczalne tematy jest niebezpieczna, bo może powodować wojnę domową, dlatego konwersacja powinna odbywać się tylko w sferze prywatnej ${ }^{74}$.

Deliberacja między zwalczającymi się wzajemnie aktorami politycznymi uchodzi współcześnie za najlepszy sposób rozwiązywania sporów politycznych. Podczas deliberowania można ustalać cele wspólne i każdy ma szansę się wypowiedzieć. Jednak z drugiej strony, wprowadzenie demokracji deliberatywnej wydaje się wizją utopijną. Utrudnieniem może być permanentna tendencja do podtrzymywania napięcia miedzy stronnictwami oraz rozszerzania sporów politycznych na coraz to inne dziedziny. Współcześnie politycy bowiem nie tylko nie przełamują przeciwieństw w jednej płaszczyźnie, lecz również przekładają je na inne obszary. Warto jednak zaznaczyć, że nie można z góry rezygnować z wysilków na rzecz poprawy jakości debaty politycznej w Polsce. Pewne elementy modelu deliberatywnego mogą się przyjąć, przynosząc korzyści ogólnospołeczne. Warto próbować przełamywać chociażby stereotypy, co winno skutkować demitologizacją polskiej sfery publicznej oraz złagodzeniem kultury politycznej.

\section{SUMMARY}

The AIM OF THE ARTICLE is to solve the problem, whether the media is responsible for the decline in the quality of a public debate. The comparison of media transmission has led to the conclusion that media was especially critically oriented towards PiS what brought about its politicization. The idea of Marcin Król is used in order to describe the reasons of media manipulation. The measure that could lead to the end of such conflicts has been suggested. That is deliberative democracy.

\section{NOTA O AUTORCE}

Urszula Panicz [panicz.ula@wp.pl] - studentka I roku studiów II stopnia na kierunku politologia na Wydziale Nauk Politycznych i Dziennikarstwa UAM, przewodnicząca Koła Samorządu Terytorialnego, redaktor gazety studenckiej BUC (szef działu Aktualności). Zainteresowania: media, polityka.

${ }^{73}$ Ibidem, S. 180 .

${ }^{74}$ Ibidem. 